\title{
Post-mortem energy metabolites, glycolytic potential, and meat quality attributes from of Dorper and Merino lambs ${ }^{\dagger}$
}

\author{
Thuthuzelwa Stempa ${ }^{1^{*}}$ and Graeme Bradley ${ }^{1}$ \\ 1 Department of Biochemistry and Microbiology, University of Fort Hare, P. Bag X1314, Alice 5700; \\ tstempa@ufh.ac.za, gbrabradley@ufh.ac.za \\ * Correspondence: tstempa@ufh.ac.za \\ + Presented at the 1st International Electronic Conference on Animals-Global Sustainability and Animals: \\ Science, Ethics and Policy, 05-20 December 2020
}

\begin{abstract}
This study was conducted to evaluate the susceptibility of the Dorper and Merino breeds to pre-slaughter conditions stress at a commercial abattoir and how it affects the quality of the meat produced. The objective of this study was to investigate differences in post-mortem energy metabolites, glycolytic potential and meat quality attributes from Muscularis longimissius thoracis et lumborum (LTL) between Dorper and Merino lambs slaughtered at a commercial abattoir. Meat samples ( 50 grams of LTL) harvested from 100 female eight-month old of the Dorper $(n=50)$ and Merino $(n=50)$ lambs were used in this study. For measuring post-mortem energy metabolites (glycogen, lactate, glucose-6-phosphate and glucose content) sampling was done on each carcass 30 minutes post-slaughter and the samples were immediately frozen $\left(-196^{\circ} \mathrm{C}\right)$ in liquid nitrogen to prevent further glycolysis. The $\mathrm{pH}$ and temperature were measured 45 minutes, 6 and 24 hours post-slaughter, and carcass measurements were taken. Colour coordinates (lightness $\left(L^{*}\right)$, redness $\left(a^{*}\right)$, yellowness $\left.\left(b^{*}\right)\right)$ were measured at 24 hours after slaughter and hue angle $\left(\mathrm{H}^{*}\right)$ and chroma $\left(\mathrm{C}^{*}\right)$ were calculated. Furthermore, thawing loss (TL), cooking loss (CL) and Warner Braztler Shear Force (WBSF) were measured after 7 days post-slaughter storage $\left(-20^{\circ} \mathrm{C}\right)$. The Dorper had lower glycogen levels thus produced meat with a high ultimate $\mathrm{pH}$ and tougher meat compared to the Merino breed. The relationships observed between post-mortem muscle metabolites, glycolytic potential and meat quality attributes indicate that meat quality is affected by glycogen levels at slaughter. The results indicate that the Dorper breed was more susceptible to pre-slaughter stress and thus produced meat with reduced quality compared to the Merino breed.
\end{abstract}

Keywords: glucose, glucose-6-phosphate, glycogen, lactate, pre-slaughter stress

\section{Introduction}

During the conversion of muscle to meat, the amount and degree of $\mathrm{pH}$ drop (from 7.4 in live muscle to 5.5 at 24 hours post-mortem) has a considerable bearing on the overall meat quality [1]. Post-mortem $\mathrm{pH}$ decline is reported to depend mostly on glycolysis, which is the breakdown down of glycogen (a muscle energy reserve) into lactate [2]. The anaerobic muscle conditions post-mortem favour glycolysis as a driver of lactate accumulation in muscles, thus lowering the $\mathrm{pH}$ [3]. Furthermore, ultimate $\mathrm{pH}(\mathrm{pHu})$ significantly affects the meat quality due to its impact on the nature of muscle proteins [4]. The levels of high muscle glycogen at slaughter have a significant role in preventing the quality defect known as dark cutting [5]. Dark, firm, dry (DFD) meat results when the normal $\mathrm{pHu}(\sim 5.5)$ at 24 hours post-moterm is not reached, and the meat will have a high $\mathrm{pH}(>6.0)$, with a dark colour and reduced tenderness [6]. In order to prevent producing meat with a $\mathrm{pHu}$ and avoid DFD meat, there is still a need to fully apprehend the underlying mechanisms of glycolytic 
metabolism [4,7]. Therefore, the objective of the study was to investigate breed effects on postmortem energy metabolites, glycolytic potential and meat quality attributes from the Muscularis longmissius thoracis et lumborum between Dorper and Merino lambs slaughtered at a commercial abattoir.

\section{Materials and Methods}

\subsection{Animals description and slaughter procedure}

A hundred 8-month old female lambs from the Dorper $(n=50)$ and Merino $(n=50)$ breeds were humanely slaughtered at a commercial abattoir. Upon arrival at the abattoir, the lambs were placed at the lairages and were given ad-libitum access to water, while feed was withdrawn.

\subsection{Meat sample harvesting}

Meat samples ( $\sim 50$ grams) for the measurement of post-mortem energy metabolites (glycogen, lactate, glucose-6-phosphate and glucose content) were collected from Muscularis longmissius thoracis et lumborum (LTL) of each carcass $\sim 30$ minutes after slaughter. After collection, visible fat was removed and samples were wrapped in foil and immediately frozen in liquid nitrogen $\left(-196^{\circ} \mathrm{C}\right)$ to prevent further glycolysis. After transportation, the samples were stored at $-80^{\circ} \mathrm{C}$ until enzymatic analysis.

\subsection{Determination of muscle glycogen, lactate, glucose-6-phosphate and glucose}

The colorimetric assay method (Sigma Aldrich, MAK016) were used to determine the level of glycogen in the muscles. The colorimetric assay method (Sigma Aldrich, MAK064) was used to determine the level of lactate in the muscles. The colorimetric assay method (Sigma Aldrich, MAK014) was used to determine the level of Glucose-6-phosphate in the muscles.The levels of glucose were determined using the Nelson-Somogyi method [8] .

\subsection{Glycolytic potential calculation}

The glycolytic potential calculation was done according to [9] where, Glycolytic Potential = [lactate] + 2 ([glycogen] + [glucose-6-phosphate] + [glucose]). The results were expressed in mmol/g.

\section{5. $\mathrm{pH}$ and temperature measurements}

Carcass $\mathrm{pH}$ and temperature were measured on the right side of each carcass by inserting the piercing probe in the LTL muscle between the 12th and 13th ribs at 45 minutes (pH45mins, Tm45mins), 6 hours (pH6hours, Tm6hours) and 24 hours ( $\mathrm{pHu}, \mathrm{Tm} 24$ hours) after slaughter using a portable $\mathrm{pH}$ meter (Hach HQ11d).

\subsection{Meat colour measurements}

Meat samples were further processed from $100 \mathrm{~mm}$ thick into $20 \mathrm{~mm}$ steaks using a band saw for Commission International De L'Éclairage Laboratory [10] colour measurements at 24 hours postmortem. The sample's surface was exposed to air for 30 minutes to facilitate 'blooming' before measurements were taken. Colour variables (lightness $\left(L^{*}\right)$, redness $\left(a^{*}\right)$, yellowness $\left(b^{*}\right)$ ) were measured using a BYK-Gardner 6692 Colour-guide 45/0 glass sealed, with a $20 \mathrm{~mm}$ diameter measurement area and illuminant D65-daylight, $10^{\circ}$ observation angle.

\subsection{Thawing loss, cooking loss and Warner Bratzler shear force}

At day seven the frozen samples were weighed (Nimbus Precision Balance NBL 214i) and allowed to thaw for 10 hours at room temperature, after thawing the samples were reweighed. The recorded 
weight differences were expressed as thawing loss \% (TL\%). After cooking, meat samples were cooled to room temperature $\left( \pm 20^{\circ} \mathrm{C}\right)$. The samples were then re-weighed to calculate the amount of water lost during cooking. Following the thawing and cooking loss measurements, Warner-Bratzler Shear Force (WBSF) test was done. From each sample, three subsamples of approximately $12.7 \mathrm{~mm}$ core diameter were extracted parallel to the long axis of the muscle fibres [11]. Each core was sheared once through the centre at an angle perpendicular to the direction of the fibre using the Warner-Bratzler shear device attached to the Universal Instron apparatus (Model 3344, crosshead speed $=400$ $\mathrm{mm} / \mathrm{min}$ ). The WBSF was measured as the peak force (Newtons) average for three cores per sample.

\subsection{Statistical analysis}

The effect of breed on muscle glycogen, lactate, glucose-6-phosphate, glucose, glycolytic potential, WCW, CCW, CF, pH(45min, 6hours, u), Tm(45min, 6hours, u) $\mathrm{L}^{*}, \mathrm{a}^{*}, \mathrm{~b}^{*}, \mathrm{H}^{*}, \mathrm{C}^{*}$ and WBSF from Dorper and Merino lambs was analysed using the PROC GLM procedure of SAS [12]. The following statistical model was used: $Y \mathrm{ij}=\mu+\alpha \mathrm{i}+\varepsilon \mathrm{ij}$ where: $\mathrm{Yij}=$ response variables (muscle glycogen, lactate, glucose-6-phosphate, glucose, glycolytic potential, WCW, CCW, CF, pH (45min, 6hours, u), $\operatorname{Tm}(45 \mathrm{~min}, 6$ hours, $\mathrm{u})\left(, \mathrm{L}^{*}, \mathrm{a}^{*}, \mathrm{~b}^{*}, \mathrm{H}^{*}, \mathrm{C}^{*}\right.$ and WBSF); $\mu=$ overall mean ; $\alpha \mathrm{i}=$ ith effect of breed (Dorper and Merino); $\varepsilon \mathrm{ijk}=$ Random error.

\section{Results and Discussion}

\subsection{Effect of breed on post-mortem energy metabolites and glycolytic potential}

In Table 1 differences $(\mathrm{P}<0.001)$ were observed for the effect of breed on the levels of muscle glycogen where, the Merino breed had higher levels of muscle glycogen compared to Dorper. Breed differences on the levels of glycogen could be attributed to differences in muscle fiber types (oxidative or glycolytic between breeds [1]. Glycogen concentration is affected by metabolic pathways of muscle fibres where oxidative muscle fiber (white) types contain less glycogen compared to predominantly Type I fibers (red) [13]. Furthermore, fasting might also influence on the levels of glycogen, as feed was not provided while the lambs were at the lairages [14].

Table 1: Least square means $( \pm \mathrm{SE})$ of post-mortem energy metabolites and glycolytic potential from Dorper and Merino lambs

\begin{tabular}{lccc}
\hline Parameters & Dorper & Merino & $P$-value \\
\hline Muscle glycogen $(\mu \mathrm{mol} / \mathrm{g})$ & $31.60 \pm 4.228$ & $54.90 \pm 4.228$ & $0.0002^{* * *}$ \\
& & & \\
Muscle Lactate $(\mu \mathrm{mol} / \mathrm{g})$ & $99.00 \pm 11.708$ & $90.38 \pm 11.708$ & 0.6034 \\
& & & 0.1467 \\
Muscle Glucose-6-phosphate $(\mu \mathrm{mol} / \mathrm{g})$ & $6.73 \pm 0.821$ & & \\
& & $0.43 \pm 0.060 .821$ & 0.7901 \\
Muscle glucose $(\mu \mathrm{mol} / \mathrm{g})$ & $0.41 \pm 0.066$ & & 0.1026 \\
Glycolytic potential $(\mu \mathrm{mol} / \mathrm{g})$ & $179 \pm 14.855$ & $211.09 \pm 14.855$ & \\
& & & \\
\hline
\end{tabular}

Significant differences at $\mathrm{P}<0.05^{*}, \mathrm{P}<0.01^{* *}, \mathrm{P}<0.001^{* * *}, \mu \mathrm{mol} / \mathrm{g}-$ micro mole/ gram 
Breed had an effect $(\mathrm{P}<0.001)$ on meat temperature at 45 minutes post-mortem, where Dorper breed had a higher meat temperature compared to the Merino breed. The Dorper had a higher $(\mathrm{P}<0.05) \mathrm{pHu}$ compared to the Merino breed. These results can be linked to the levels of muscle glycogen shown in Table 1, where the Dorper had lower levels of muscle glycogen compared to Merino breed. These results indicate that the Dorper breed had tougher meat compared to the Merino.

Table 1: Least square means $( \pm \mathrm{SE})$ of meat quality attributes from the Muscularis longimissius thoracis et lumborum of Dorper and Merino lambs

\begin{tabular}{|c|c|c|c|}
\hline Parameters & Dorper & Merino & P-Value \\
\hline $\mathrm{pH}_{45 \min }$ & $6.68 \pm 0.034$ & $6.68 \pm 0.034$ & 0.9569 \\
\hline $\mathrm{T}_{\mathrm{m} 45 \min }\left({ }^{\circ} \mathrm{C}\right)$ & $34.13 \pm 0.174$ & $29.31 \pm 0.174$ & $<0.0001^{* * *}$ \\
\hline pH 6 hours & $6.09 \pm 0.021$ & $6.04 \pm 0.021$ & 0.0966 \\
\hline Tm6hours $\left({ }^{\circ} \mathrm{C}\right)$ & $14.60 \pm 0.154$ & $16.12 \pm 0.154$ & $<0.0001^{* * *}$ \\
\hline $\mathrm{pHu}$ & $6.05 \pm 0.022$ & $5.98 \pm 0.022$ & $0.0412^{*}$ \\
\hline $\mathrm{T}_{\mathrm{m} 24 \text { hours }}\left({ }^{\circ} \mathrm{C}\right)$ & $15.21 \pm 0.165$ & $16.79 \pm 0.165$ & $<0.0001^{* * *}$ \\
\hline$L^{*}$ & $38.32 \pm 0.479$ & $38.80 \pm 0.479$ & 0.4828 \\
\hline$a^{*}$ & $14.97 \pm 0.291$ & $15.09 \pm 0.291$ & 0.7686 \\
\hline$b^{*}$ & $6.56 \pm 0.388$ & $7.38 \pm 0.388$ & 0.1382 \\
\hline $\mathrm{C}^{*}$ & $16.49 \pm 0.387$ & $16.90 \pm 0.387$ & 0.4603 \\
\hline $\mathrm{H}^{*}$ & $0.40 \pm 0.017$ & $0.45 \pm 0.017$ & $0.0349^{*}$ \\
\hline TL\% & $11.92 \pm 0.826$ & $14.51 \pm 0.826$ & $0.0291^{*}$ \\
\hline CL\% & $28.63 \pm 1.301$ & $26.90 \pm 1.301$ & 0.3495 \\
\hline WBSF (N) & $37.35 \pm 1.232$ & $31.78 \pm 1.232$ & $0.0019^{* *}$ \\
\hline
\end{tabular}

Significant differences at $\mathrm{P}<0.05^{*}, \mathrm{P}<0.01^{* *}, \mathrm{P}<0.001^{* * *}, \mathrm{WCW}=$ warm carcass weight, $\mathrm{CCW}=$ cold carcass weight, $\mathrm{CF}$-carcass fatness, $\mathrm{pH}_{45 \mathrm{~min}}-\mathrm{pH}$ at 45 minutes, $\mathrm{T}_{\mathrm{m} 45}=$ meat temperature at 45 minutes, $\mathrm{pH} 24$ hours $-\mathrm{pH}$ at 24 hours, $\mathrm{Tm} 24$ hours - meat temperature at 24 hours, $L^{*}=$ Lightness, $\mathrm{a}^{*}=$ Yellowness, $\mathrm{b}^{*}=$ Redness, $\mathrm{C}^{*}=$ Chroma, $\mathrm{H}^{*}=$ Hue angle, $\mathrm{TL}=$ thawing loss, $\mathrm{CL}$ cooking loss, WBSF= Warner Braztler shear force, $\mathrm{kg}$ - kilogram, $\%=$ percentage, $\mathrm{N}-$ Newtons, $\mathrm{mm}=$ millimetre, ${ }^{\circ} \mathrm{C}=$ Degrees Celsius

Meat with a high ultimate $\mathrm{pH}$ is deemed unacceptable to consumers as it is associated with dark, firm and dry meat which is prone to microbial spoilage [15]. In this study Merino breed produced meat of better quality compared to the Dorper. The Merino might have had a better stress response compared to the Doper, which might have been more susceptible to the pre-slaughter stress 
environment. Stempa et al.[16] reported that pre-slaughter stress response differs owing to breed differences. Tenderness can be linked to the rate of $\mathrm{pH}$ decline after slaughter, if the $\mathrm{pH}$ at $45 \mathrm{~min}$ is very high and carcass temperature is rapidly lowered a condition known as cold shortening can result resulting in tough meat [17].

\section{Conclusion}

These results indicate that breed does have an effect on post-mortem muscle metabolites and glycolytic potential expect of muscle glycogen. The Dorper breed had lower glycogen levels thus produced meat with a high ultimate $\mathrm{pH}$ and tougher meat compared to the Merino breed. The relationships observed between post-mortem muscle metabolites, glycolytic potential and meat quality attributes indicate that meat quality is affected by glycogen levels at slaughter. Hence care should be taken during the pre-slaughter period to avoid excessive loss of muscle glucose since it will have a negative impact on the meat quality of lambs. Further research on how to avoid excessive loss of muscle glycogen prior to slaughter is needed to avoid economic losses due to dark cutting meat.

Acknowledgments: This work was funded by the National Research Foundation-Scarce Skills Post-Doctoral Scholarship (Grant number: 116651) and Meat Industry Trust (MIT).

\section{References}

1. Immonen, K.; Kauffman, R.G.; Schaefer, D.M.; Puolanne, E. Glycogen concentrations in bovine longissimus dorsi muscle. Muscle Sci. 2000, 54,163-167. doi.org/10.1016/S0309-1740(99)00090-X.

2. Pösö, A.R.; Puolanne, E. Carbohydrate metabolism in meat animals. Meat Sci. 2005, 70(3), 423-434. doi.org/10.1016/j.meatsci.2004.12.017.

3. Ryu, Y.C.; Kim, B.C. The relationship between muscle fiber characteristics, postmortem metabolic rate, and meat quality of pig longissimus dorsi muscle. Meat Sci. 2005, 71, 351-357. doi.org/10.1016/j.meatsci.2005.04.015.

4. Scheffler, T.L.; Gerrard, D.E. Mechanisms controlling pork quality development: The biochemistry controlling postmortem energy metabolism. Meat Sci. 2007, 77(1), 7-16. doi.org/10.1016/j.meatsci.2007.04.024.

5. Pethick, D.W.; Rowe, J.B. The effect of nutrition and exercise in carcass parameters and the level of glycogen in skeletal muscle of Merino sheep. Aust. J. Agric. Res. 1996, 47,525-537.

6. Tarrant, P.V. Animal behaviour and environment in the dark-cutting condition in the Dark-Cutting condition in beef. Irish J. Food Sci. Tech. 1989, 13, 1-21.

7. Chauhan, S.S.; England, E.M. Postmortem glycolysis and glycogenolysis: insights from species comparisons. Meat Sci. 2018, 144, 118-126. doi.org/10.1016/j.meatsci.2018.06.021.

8. Nelson N. A photometric adaptation of the Somogyi method for the determination of glucose. J. Biol. Chem. 1944, 153(2), 375-380.

9. Monin, G.;Sellier, P. Pork of low technological quality with a normal rate of muscle pH fall in the immediate post-mortem period: the case of the Hampshire breed. Meat Sci. 1985, 13, 49-63. doi.org/10.1016/S0309-1740(85)80004-8.

10. Commission International De L' Éclairage (CIE). 1976. Colorimetry. (Second edition). CIE, Vienna, Switzerland. 
11. AMSA. 1995 Research guidelines for cookery, sensory evaluation and instrumental tenderness measurements of fresh meat. Chicago, Illinois: American Meat Science Association in cooperation with National Live Stock and Meat Board.

12. Statistical Analysing System .2009. 'SAS user's guide: statistics.'6th edn. (SAS Institute Inc.: Cary NC).

13. Klont, R.E.; Brocks, L.; Eikelenboom, G. Muscle fiber type and meat quality. Meat Sci. 1998, 49(1), S219S229. doi.org/10.1016/S0309-1740(98)90050-X.

14. Díaz, M.T.; Viera, C.; Pérez, C.; Lauzurica, S.; González de Chávarri, E.; Sánchez, M.; De la Fuente, J. The effect of lairage time $(0 \mathrm{~h}, 3 \mathrm{~h}, 6 \mathrm{~h}$ or $12 \mathrm{~h})$ on glycogen content and meat quality parameters in suckling lambs. Meat Sci. 2014, 96, 653-660. doi.org/10.1016/j.meatsci.2013.10.013.

15. Ferguson, D.M.; Bruce, H.L.; Thompson, J.M.; Egan, A.F.; Perry, D.; Shorthose, W.R. Factors affecting beef palatability - Farmgate to chilled carcass. Aust. J. Exp. Agr. 2001, 41(7), 879-891.

16. Stempa, T.; Muchenje, V.; Abrahams, A.M.; Bradley, G.Sex and breed affect plasma glucose, lactate, cortisol, meat quality but not muscle glycolytic potential of Dorper and Merino lambs. Anim. Prod. Sci. 58(5) 2016, 958-964. doi.org/10.1071/AN16522.

17. McGeehin, B.; Sheridan, J.J.; Butler, F. Factors affecting the $\mathrm{pH}$ decline in lamb after slaughter. Meat Sci. 2001, 58, 79-84. doi.org/10.1016/S0309-1740(00)00134-0.

(C) 2020 by the authors. Submitted for possible open access publication under the terms and conditions of the Creative Commons Attribution (CC BY) license (http://creativecommons.org/licenses/by/4.0/). 